\title{
PENGEMBANGAN BUSANA KERJA DARI KAIN SONGKET BIMA
}

\author{
Awaluddin M. Abdillah"), I.G. Sudirtha' ${ }^{2)}$, I.D.A Made Budhyani ${ }^{3)}$ \\ Program Studi Pendidikan Kesejahteraan Keluarga \\ Universitas Pendidikan Ganesha \\ Singaraja, Indonesia
}

e-mail: awaluddinabdillah@gmail.com, gede.sudirtha@undiksha.ac.id, ayu.budhyani@undiksha.ac.id

\begin{abstract}
Abstrak
Tujuan dari penilitian ini yaitu untuk: Mengetahui hasil pengembangan busana kerja dari kain songket Bima. Jenis dari penelitian ini adalah penelitian Research and Development atau penelitian dan pengembangan dengan model PPE (Planning, Production and Evaluation) .Isntrumen yang digunakan dalam mengumpulkan data yaitu kuesioner. Data yang terkumpul dianalisis dengan teknik analisis deskriptif kuantitatif dan teknik analisis deskriptif kualitatif. Penelitian dilakukan dengan uji coba produk yang melibatkan dua ahli busana. Adapun hasil dari penelitian ini yaitu : 1) Dari hasil uji isi untuk kuisioner pengembangan busana kerja , terdapat 3 indikator yang terdiri dari 7 butir pertanyaan yang dinyatakan valid oleh ahli isi. 2) Hasil produk jika di konversikan kedalam persentase memiliki kualifikasi sangat baik dengan tingkat pencapaian 92,5\%. 3) Perlu diperhatikan kesesuaian desain dengan hasil jadi busana kerja. 4). Pemilihan bahan yang tepat dapat menunjang pengembangan busana kerja..
\end{abstract}

Kata Kunci : PPE, Busana Kerja, Kain songket Bima.

\begin{abstract}
The aim of this study was to acknowledge the result of the development of work uniform from Bima songket cloth. Type of study used in this study was Research and Development with PPE (Planning, Production and Evaluation) model. The instrument used to collect the data was questionnaire. The data gathered then being analyzed by using descriptive qualitative and descriptive qualitative technique. The research was done by testing the product with involving the experts of contents and fashion. The result of the study was: 1) From the testing of contents for questionnaire in the development of work uniform, there were 3 indicators which consist of 7 questions that are declared as valid by contents expert. 2) The percentage of the converted product showed to have excellent qualification with achievement level in 92,5\%. 3) Need to be noticed the comformity between the design and the result of work uniform. 4) The proper choice of the material can support the work uniform development.
\end{abstract}

Key words: PPE, Work Uniform, Bima songket cloth.

\section{PENDAHULUAN}

Busana dalam arti umum adalah bahan tekstil atau bahan lainnya yang sudah dijahit atau tidak dijahit yang di pakai atau di sampirkan untuk menutup tubuh seseorang. Sebagai contoh kebaya dan kain panjang atau sarung, rok, blus, blazer, bebe, celana rok, celana pendek atau celana panjang, kemeja, T-shirt, piyama, singlet, kutang atau Buste Houder $(B H)$, rok dalam, bebe dalam. Dalam pengertian lebih luas sesuai dengan perkembangan peradaban manusia, khususnya bidang busana termasuk kedalam aspek-aspek yang menyertainya sebagai perlengkapan itu sendiri. Baik dalam kelompok (milleneries) maupun aksesoris (accessories).

Busana kerja adalah busana yang dipakai ketika melakukan pekerjaan sesuai dengan tugasnya masing-masing (Riyanto: 2003) busana kerja dapat digolongkan menjadi 2 yaitu busana kerja dalam ruangan (indoor) dan busan kerja luar ruangan (outdoor). Busana kerja memiliki 
beberapa karakteristik yaitu : a) Busana kerja harus menunjang aktivitas pekerjaan. b) Model busana kerja wanita harus serasi, sederhana seperti tidak banyak lipitan, kerutan, ploi, jahitan tindis dan saku. c) Pemilihan kain yang dapat memberikan kesan nyaman, tidak tembus pandang dan mengkilap, tidak tebal dan kasar.

Kain tradisional Bima berasal dari Propinsi Nusa Tenggara Barat. Kain tradisional Bima terdiri dari beberapa jenis. Secar umum, ada empat jenis yaitu : kain Tembe, Sambolo, Weri atau Malanta Salolo, dan baju Mbojo. Namun pada penelitian ini hanya bertolak pada Tembe yang merupakan kain tenun berupa sarung dan ditenun dengan cara tradisional yang terbuat dari benang kapas. Kain tenun Bima dibagi menjadi dua yaitu : Tembe Sonke atau sarung songket dengan warna dasar coklat, merah hati dan hitam. Untuk motifnya menggunakan motif berupa garisgaris kecil dengan paduan bunga Samobo satako, kakando dan bunga Pado waji. Untuk penunjang keindahan, motif tersebut dihiasi dengan benang emas dan perak. Kedua, kain Tembe Kafa nae, yaitu sarung tenun yang dibuatdari benang khusus yang berasal dari penenun itu sendiri

Sedangkan karakteristik kain songket Bima bertekstur sedikit kasar terbuat dari benang, memiliki warna yang cerah, dan memiliki motif tumbuhan (flora), bangun datar (persegi, segi delapan), hewan (fauna). Dari karakteristik tersebut kain songket Bima memiliki kelayakan untuk dijadikan sebagai busana kerja. Berdasarkan pengamatan yang peneliti lakukan, Busana kerja di daerah bima masih menggunakan busana yang terbuat dari kain yang umum dipakai. Misalanya, dari kain batik, kain polos dan lain-lain. Namun belum banyak yang menggunakan kain tradisional untuk busana kerja. Seperti pada hari-hari tertentu yang dianjurkan untuk memakai busana dari kain tradisional yaitu hari kamis atau hari jumat. Berdasarkan hal tesebut maka penelitian ini berinisiatif untuk mengembangkan busana kerja dari kain songket Bima supaya dapat dipakai agar mencerminkan budaya Bima dalam tempat kerja. Adapun instansi yang menjadi acuan peneliti dalam pembuatan busana ini yaitu Bank NTB Syariah, alasan dipilihnya Bank ini sebagai acuan adalah peneliti ingin memfokuskan kain songket khas Bima dalam rangka melestarikan serta menambah nilai budaya pada seragamnya.

Karena busana yang dikembangkan adalah busana kerja, maka digunakan teknik pengembangan model Planning, Production, dan Evaluation (PPE). Alasan pemilihan model pengembangan ini dikarenakan model ini fokus dari perancangan dan penelitian pengembangan bersifat analisis dari awal sampai akhir, yang meliputi Perancangan, Produksi dan Evaluasi. Dimana pengembangan ini sederhana dan mudah dipelajari. Teknik pengembangan model PPE ini merupakan salah satu model pengembangan suatu produk baru, atau menyempurnakan produk yang telah ada dan dapat dipertanggung jawabkan hasilnya. Model PPE memberi peluang untuk melakukan evaluasi terhadap aktivitas pengembangan pada setiap tahap. Diharapkan dengan menggunakan model pengembangan ini, dapat dikembangkannya sebuah produk berupa busana kerja dari kain songket Bima.

Jika dilihat dari perkembangan busana kerja yang terus berkembang ada banyak busana kerja yang dibuat dengan berbagai macam kain, maka penulis akan mencoba berkreasi dengan menggunakan kain songket Bima dalam mewujudkan busana kerja. Berdasarkan uraian di atas, diangkat sebuah judul penelitian yaitu "Pengembangan Busana Kerja dari Kain Songket Bima". Adapun jenis busana yang dibuat yaitu busana kerja untuk wanita dan pria dengan bahan utama kain songket Bima berwarna dasar hijau dan dipadukan dengan sedikit kain polos berwarna serasih dengan motif kain songket yang dipilih.sedangkan model yang dibuat berupa blus menggunakan lengan panjang beserta bawahannya berupa rok panjang sampai mata kaki dan atasan busana pria yang bemodel seperti jas dengan lengan pendek serta menggunakan kerah sanghai.

\section{METODE PENELITIAN}

Sebuah penelitian hendaknya memiliki metode dalam pelaksanaannya. Sugiyono (2019, p.2) berpendapat bahwa, 
"metode penelitian pada dasarnya merupakan cara ilmiah untuk mendapatkan data dengan tujuan dan kegunaan tertentu". Dalam pengembangan busana kerja ini, peneliti menggunakan metode penelitian dan pengembangan (Research and Development/R\&D)..

Dalam penelitian ini, peneliti mengadopsi langkah-langkah penelitian dan pengembangan model Planning, Production, Evaluation (PPE) menurut Richey dan Klein (2009), yaitu dengan rincian sebagai berikut: 1) Planning (Perencanaan) Tahap planning dalam penelitian pengembangan ini adalah perencanaan dalam pembuatan busana kerja. Perencanan yang dilakukan yakni menganalisis model busana kerja yang hendak dikembangkan,selain itu penelliti juga menggunakan kain songket Bima yang memiliki motif bermacam-macam. Kemudian peneliti membuat suatu desain busana sesuai dengan karakteristik busana kerja itu sendiri.Peneliti membuat beberapa desain sketsa, yang terdiri dari desain busana pria. Kemudian dari desain tersebut dipilih dua desain yang sesuai untuk dijadikan sebagai busana kerja.. Setelah dua desain sketsa yang dipilih, kemudian membuat desain produksi dan analisis desain. Peneliti menggunakan teknik wawancara untuk menggali informasi dan studi dokumentasi tentang kain songket Bima. 2) Production (Produksi) Tahap kedua pada model PPE yaitu production atau produksi. Produksi dalam penelitian ini menghasilkan dua produk busana kerja wanita dan pria. Beberapa ide diambil dari warna busana dan motif kain songket Bima. Selanjutnya dimulai dari pengumpulan bahan,, pengelolaan bahan dan terakhir produksi. Bahan-bahan yang dikumpulkan berupa kain untuk bahan utama, kain untuk bahan furing/linning, benang, dan alat-alat jahit. Setelah alat dan bahan terkumpul, dilakukan pengelolaan bahan oleh peneliti, yaitu dengan membuat suatu prodak busana kerja dari kain songket Bima dengan teknik jahit yang digunakan dalam membuat busana. 3) Evaluation (Evaluasi). Evaluasi merupakan kegiatan menilai produk yang dilakukan oleh ahli (expert judgment), Kegiatan evaluasi ini dilakukan guna mengetahui kekurangan atau kelemahan produk serta masukan ahli sehingga produk dapat memiliki kelayakan dan kualitas yang lebih baik untuk digunakan. Hal ini seperti diungkapkan oleh Thiagarajan (1974) bahwa,"Penilaian ahli merupakan teknik untuk memperoleh saran guna peningkatan produk, untuk membuat produk lebih sesuai, efektif, dapat digunakan dan memiliki kualitas teknis yang tinggi".

Teknik pengumpulan data yang digunakan ialah Teknik deskriptif kuantitatif dan Teknik deskriptif kualitatif. Penelitian ini bertujuan untuk mengetahui hasil pengembangan busana kerja dari kain songket Bima. Penelitian ini dilaksanakan di laboratorium praktikum Pendidikan kesejahteraah keluarga tata busana UNDIKSHA.

Sumber data dari penelitian ini yaitu dengan melakukan uji produk dengan dinilai oleh dua orang ahli busana. Hal-hal yang dinilai pada Uji Produk sudah ditentukan dan tertera pada instrument penelitian. Berikut merupakan hasil uji produk dari pengembangan busana kerja dari kain songket Bima

\section{HASIL DAN PEMBAHASAN}

Dalam sebuah penelitian tentunya memerlukan banyak perangkat pendukung agar tercapainya penelitian yang diinginkan salah satunya adalah metode penelitian. Menurut Sugiyono (2019) Research and Development merupakan metode penelitian yang digunakan untuk meneliti dalam upaya mengembangkan produk yang telah ada (inovasi) maupun untuk menciptakan produk baru (kreasi) yang teruji. Untuk dapat menghasilkan produk tertentu digunakan penelitian yang bersifat analisis kebutuhan dan menguji keefektifan produk tersebut supaya berfungsi dimasyarakat luas, maka diperlukan penelitian untuk menguji keefektifan produk tersebut. Seperti pada model pengembangan yang dikemukakan oleh Richey and Klein (2009) terdiri dari planning, production, and evaluation (PPE). Penelitian ini fokus pada perancangan dan penelitian pengembangan bersifat analisis dari awal sampai akhir, yang meliputi Perancangan, Produksi dan Evaluasi. Planning (Perancangan) berarti 
kegiatan membuat rencana produk yang akan dibuat untuk tujuan tertentu. Perencanaan diawali dengan analisis kebutuhan yang dilakukan melalui penelitian dan study literature. Production (memproduksi) adalah kegiatan membuat produk berdasakan rancangan yang telah dibuat. Evaluation (evaluasi) merupakan kegiatan menguji, menilai seberapa tinggi produk telah memenuhi spesifikasi yang telah di tentukan.

Seperti pada penelitian yang dilakukan oleh Haryawati, dkk (2018). Pembuatan Busana Fantasi Dengan Sumber Ide Dramatari Calonarang. Penelitian ini bertujuan untuk mendeskripsikan proses pembuatan busana fantasi dengan sumber ide Dramatari Calonarang, mendeskripsikan hasil dari pembuatan busana fantasi dengan sumber ide Dramatari Calonarang. Penelitian ini merupakan penelitian pengembangan (Research and Development), menggunakan model pengembangan PPE. Proses penelitian pengembangan busana ini dilakukan melalui beberapa tahap, yaitu yang terdiri dari 3 tahap yaitu: Perencanaan (planning), produksi (production), evaluasi (evaluation). (1) Pengumpulan data yang digunakan dalam pengembangan ini adalah angket. Dan juga penelitian yang dilakukan Lestari, dkk (2019). Pengembangan Busana Fantasi Dengan Sumber Ide Kekaisaran Jepang. Tujuan Penelitian ini adalah mendeskripsikan proses pengembangan busana fantasi, mengetahui hasil pengembangan pembuatan busana fantasi dengan sumber ide Kekaisaran Jepang. Dalam penelitian ini menggunakan metode $R \& D$ (Research and Development) dengan model penelitian pengembangan ADDIE (Analysis-Design-Development-

Implementation-Evaluation) pada setiap tahapannya.

Dalam pengembangan busana kerja dari kain songket Bima ini menggunakan model pengembangan PPE (Planning, Production, Evaluation). Tahap planning dalam penelitian pengembangan ini adalah perencanaan dalam pembuatan busana kerja. Perencanan yang dilakukan yakni menganalisis karakteristik busana kerja, karakteristik kain songket Bima, warnawarna dan kombinasi yang terdapat pada busana kerja, selain. Selanjutnya membuat suatu desain busana sesuai dengan karakteristik busana kerja. Penulis membuat beberapa desain kemudian dipilih satu desain untuk busana wanita dan Pria yang terbaik untuk dikembangkan.

Kemudian dilanjutkan ke-tahap produksi, dalam tahap ini terdapat 3 langkah yaitu, persiapan dan pelaksanaan. Pada tahap persiapan terdiri dari pengambilan ukuran untuk pembuatan busana kerja, pembuatan pola dan merancang bahan dan harga. Tahap pelaksanaan terdiri dari memotong bahan sampai dengan proses menjahit. Di tahap evaluasi, mengecek keseluruhan dari bagian-bagian busana.

Langkah selanjutnya yaitu evaluasi.

Pada tahap ini, melakukan evaluasi terhadap hasil uji produk dari ahli busana. Hasil evaluasi akan dijadikan sebagai acuan dalam mengembangkan produk yang sejenis. Untuk pengambilan data uji coba, menggunakan lembar kuisioner. Subyek uji coba dari penelitian ini adalah 2 orang ahli yang keduanya merupakan dosen busana

Metode penelitian yang digunakan yaitu penelitian pengembangan (Research and Development). Model penelitian pengembangan yang digunakan yaitu penelitian pengembangan model PPE. Model penelitian ini terdiri dari 3 langkah yaitu, Perencanaan (Planning), Produksi (Production), dan Evaluasi (Evaluation). Pada tahap pertama, peneliti melakukan analisis kebutuhan serta membuat rancangan produk yang berupa desain produk. Sebelum memulai pada tahap mendesain penulis menganalisis busana, warna-warna dan motif yang terdapat pada busana kerja.

Adapun bagian-bagian busana kerja yang akan dibuat antara lain : a) Baju (atasan wanita dan pria). Baju atasan wanita berupa blus dengan kerah model sanghai, berlengan panjang dan diberi aksen motif pada sisi kanan bagian tengah muka yang bermodel overslag serta diaplikasikan dengan kain polos pada bagian sisi. Juga terdapat kantong bagian kanan pinggang. Baju atasan pria berupa safari dengan kerah sanghai berlengan pendek dan memiliki aksen motif pada sisi 
kanan bagian tengah muka, dan diberi kantong berbentuk asimetris pada bagian kiri dada. Serta di aplikasikan kain polos di bagian sisi. b) Rok (bawahan wanita) Rok bermodel span dengan panjang hingga mata kaki. Terdapat belahan tertutup pada bagian belakang rok. Sehingga menambah keindahan pada bagian belakang rok. Desain busana kerja yang terpilih, dibuat berdasarakan karakteritik busana kerja dan karakteristik kain songket. Busana kerja yang penulis kembangkan menggunakan kain songket berwarna hijau dan ungu kecoklatan yang dikombinasikan dengan kain polos yang senada dengan warna kain.. Pemilihan warna, bentuk serta motif juga serasi antara desain wanita dan pria

Setelah menentukan desain yang akan dikembangkan, kemudian dilanjutkan ketahap produksi. Pada tahap produksi dilakukan proses pengembangan produk melalui langkah-langkah pengembangan. Pada tahap pengembangan busana kerja menggunakan bahan dasar kain songket bermotif segi delapan dan kain polos kemudian dilengkapi dengan Adapun tiga tahapan dalam proses produksi ini yaitu, tahap persiapan, tahap menjahit dan finishing.

Berikut merupakan hasil jadi busana kerja dari kain songket Bima.

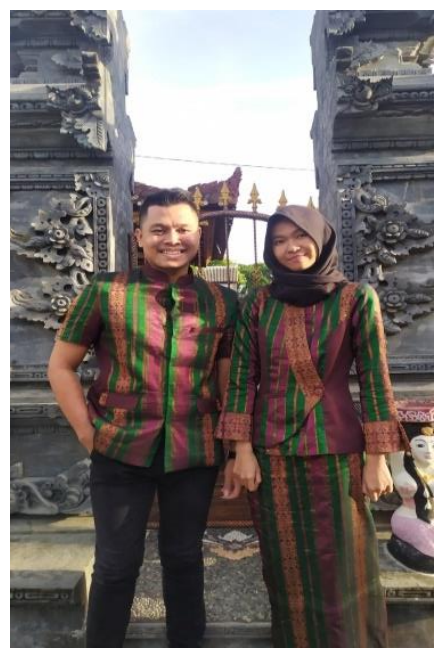

Gambar1. Hasil Pengembangan Busana

Kerja Dari Kain Songket Bima

Sumber: Dokumentasi Sendiri
Setelah itu dlanjutkan pada tahap evaluasi. Metode pengumpulan yang digunakan untuk data ini berupa kuisioner yang diberikan kepada subyek penelitian yaitu 2 orang ahli busana. Menurut chaplin (1999) angket merupakan seperangkat pertanyaan yang membahas suatu topik tunggal yang berkaitan untuk di berikan kepada individu guna dapat mengetahui sejauh mana individu tersebut memahami sebuah bahan ajar atau modul yang dikembangkan oleh peneliti. Winkel (1991) menegaskan bahwa angket merupakan suatu daftar atau sekumpulan pertanyaan tertulis dan memiliki pilihan jawaban yang tergabung menjadi satu kesatuan untuk digunakan sebagai instrument dalam proses pengambilan data penelitian. Dari kedua pendapat ini Tritjahjo (2014) dalam bukunya yang berjudul asesmen non-tes menyimpulkan bahwa angeket merupakan seperangkat pertanyaan tertulis yang terinci, lengkap dan dirumuskan sedemikian rupa agar mendapat jawaban yang objektif mengenai hal yang sedang diteliti oleh peneliti. Data tersebut kemudian dianalisis menggunakan rumus rerata sebagai berikut.

$$
N=\frac{\text { Skor Perolehan }}{\text { Skor Maksimal }} \times 100 \%
$$

Berikut merupakan tabel perolehan nilai.

Tabel 1. Hasil Uji Ahli Produk 


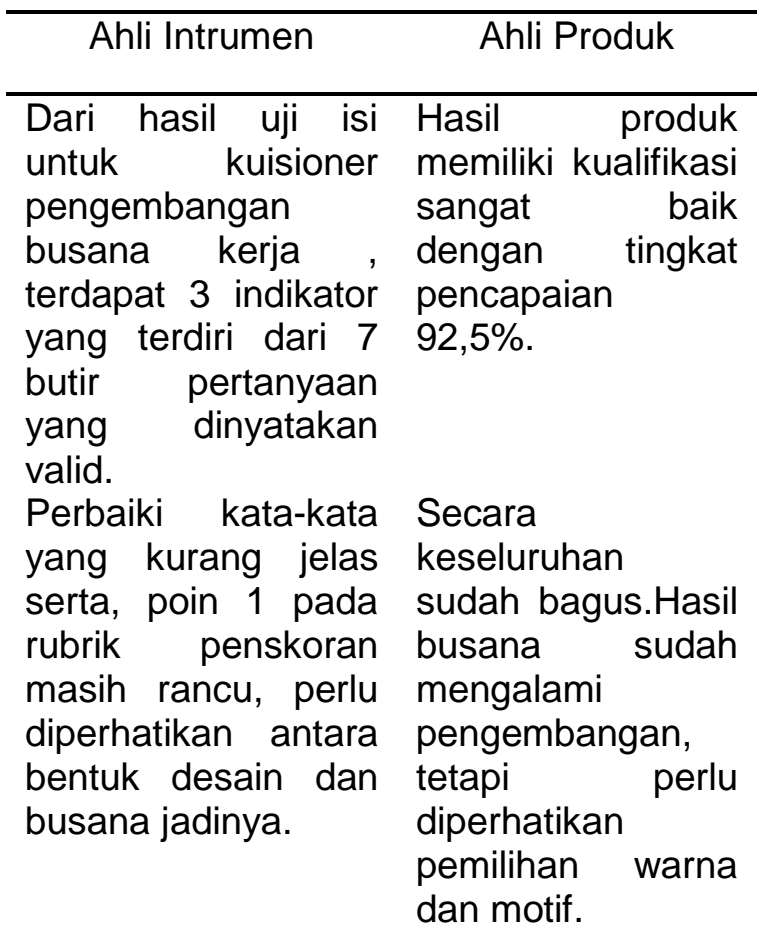

Data yang diperoleh dari hasil uji produk yang terdiri dari 2 orang uji ahli, selanjutnya dianalisis menggunakan rumus rerata sebagai berikut.

$$
\begin{aligned}
& \text { presentase ahli } 1=\frac{19}{21} \times 100 \%=90 \% \\
& \text { presentase ahli } 2=\frac{20}{21} \times 100 \%=95 \% \\
& \text { rerata presentase }=\frac{185}{2}=92,5 \%
\end{aligned}
$$

Pengembangan produk berupa busana kerja dari kain songket Bima merupakan sebuah produk yang diciptakan dengan kreasi yang baru. Dalam pengembangan busana kerja ini mengambil bentuk dan warna yang disesuaikan dengan karakteristik dari busana kerja dan karakteristik kain songket Bima. Pada pembuatan busana menggunakan bahan kain songket Bima yang dikombinasikan dengan kain polos berwarna coklat.

Namun ada beberapa masukan dari para ahli yang menjadi tolak ukur perbaikan pada pengembangan ini yaitu ; lebih memperhatikan bentuk desain dengan hasil jadi busana kerja, model busana kerja dari kain songket Bima harus lebih sesuai dengan karakteristik busana kerja, pemilihan bahan yang cocok dengan karakteristik busana kerjapun harus diperhatikan baik dari segi warna, bentuk dan tektur kainnya. Karena bagaimanapun juga sebuah penelitian tidak luput dari kesalahan. Maka dari itu dari beberapa masukan para ahli busana akan sangat bermanfaat dalam penelitian selanjutnya.

Dari hasil penelitian yang telah dipaparkan, maka busana kerja yang dikembangkan memiliki kualifikasi sangat baik berdasarkan hasil dari uji ahli busana. Adapun hasil dari data menggunakan analisis deskritif kualitatif adalah sebagai berikut.

Tabel 2. Analisis Data Deskriptif Kualitatif

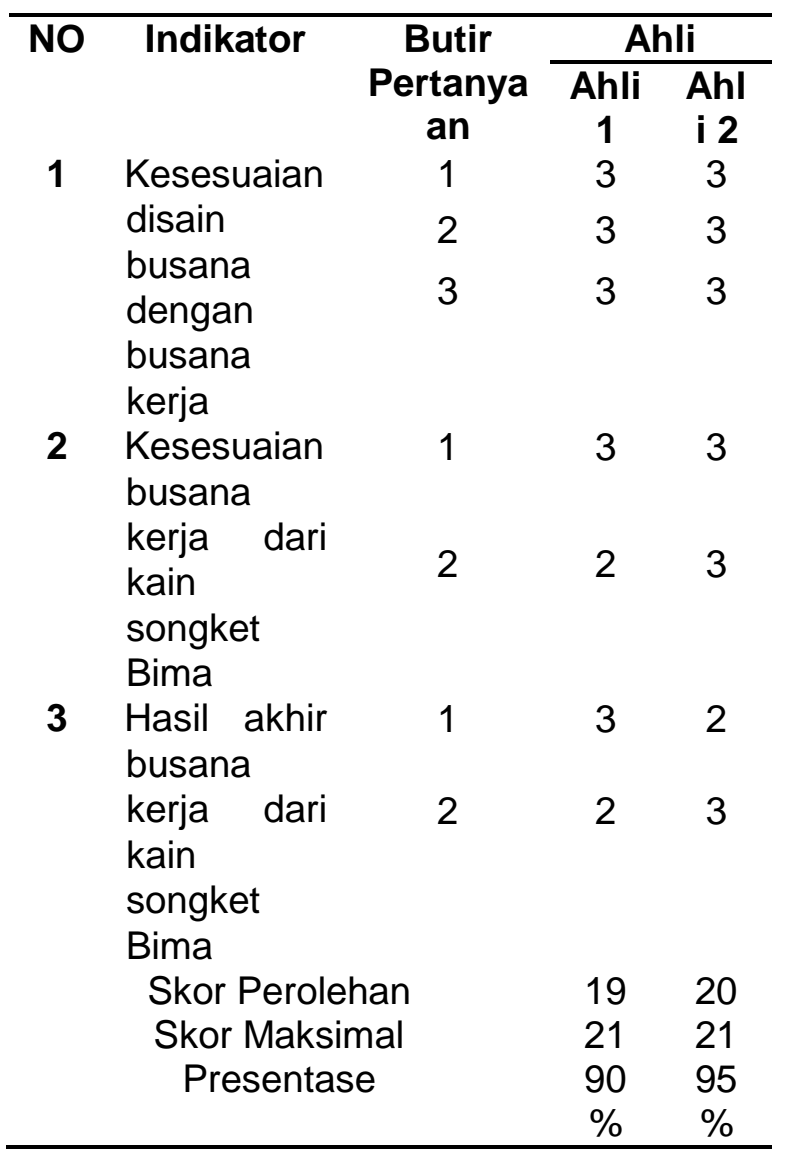

\section{SIMPULAN DAN SARAN}

Berdasarkan pengolahan dan analisis yang telah dilakukan, dapat disimpulkan bahwa dari pengembangan busana kerja dari kain songket Bima memiliki kualifikasi sangat baik dengan pencapaian $92,5 \%$. Jadi dapat disimpulkan bahwa pengembangan busana kerja dari 
kain Songket Bima mengalami pengembangan dan layak di jadikan referensi bagi penelitian yang serupa. .

\section{DAFTAR PUSTAKA}

Agustini, Sudiartha, G., Angendari, M. D. 2019. Pengembangan Busana Pesta Malam dengan Sumber Ide Dari Mitologi Kerajaan Yunani. Tersedia di: https://ejournal.undiksha.ac.id/inde x.php/JJPKK/article/view/22152.

Diakses 10 Oktober 2019.

Arikunto, S. 2006. Metode Penelitian Kualitatif. Jakarta: Bumi Aksara.

Borg, W R \& Gall, M D. 2003. Educational Research: an Introduction (7. ed). New York: Logman Inc.

Chandra, J. 1994. Kreativitas, Bagaimana Menanam ,Membangun dan Mengembangkannya. Yogyakarta : Kanisius.

Ernawati, Izweni, Weni, N. 2008. Tata Busana Jilid 1 untuk Sekolah Menengah Kejuruan. Jakarta: Direktorat Pembinaan Sekolah Menengah kejuruan.

Haryawati, I L A., Sudiartha, I G., Angendari, M.D. 2019. Pembuatan Busana Fantasi dengan Sumber ide Dramatari Calonarang, tersedia di:

https://ejournal.undiksha.ac.id/inde x.php/JJPKK/article/view/22151. Diakses 11 Januari 2020.

Khayati, E. Z. 1998. Pembuatan busana III. Yogyakarta: IKIP Yogyakarta.

Lestari, A P R P., Sudirtha, I G., Angendari, $M$ D. 2019. Pengembangan Busana Fantasi dengan Sumber Ide Kekaisaran Jepang. Tersedia di:

https://ejournal.undiksha.ac.id/inde x.php/JJPKK/article/view/15991. Diakses 11 Januari 2020.

Munandar, S.C. Utami. 1992. Mengembangkan Bakat dan Kreativitas Anak Sekolah. Jakarta: PT. Gramedia Widiasarana Indonesia.
Ngalimun, 2013. Perkembangan dan Pengembangan Kreativitas. Yogyakarta: Aswaja Pressindo

Nurcahyani, L. $2018 . \quad$ Strategi Pengembangan Produk Kain Tenun Ikat Sintang. Tersedia di: https://jurnaldikbud.kemdikbud.go.i d/index.php/ipnk/ article/view/530. Diakses 11 Januari 2020.

Riyanto, A. A. 2003. Desain Busana. Bandung: Yapemdo.

Robert, B. M. 2009. Instructional DesignThe ADDIE Approach. New York: Springer.

Rukmana, N.S.R., Yarmaidi, Y., Suwarni, N. 2014. Kain Songket dalam Upaya Pelestarian Budaya Daerah Palembang Muara Penimbung Ulu. Tersedia di: https://www.neliti.com/id/publication s/247898/kain-songket-dalamupaya-pelestarian-budaya-daerahpalembang-di-muara-penimbung.

Diakses 11 Januari 2020.

Soekarno. 2002. Buku Penuntun Membuat Pola Busana Tingkat Dasar. Jakarta: PT Gramedia Pustaka Utama.

Sugiyono. 2009. Metode Penelitian Kuantitatif, Kualitati Dan R\&D. Bandung : Alfa Beta.

Sugiyono. 2014. Metode Penelitian Kuantitatif, Kualitatif dan R\&D. Jakarta: Alfabeta.

Sugiyono. 2019. Metode Penelitian Kuantitatif, Kualitatif dan $R \& B$. Jakarta: Alfabeta.

Tegeh, Made Dkk. 2014. Model Penelitian Pengembangan. Yokyakarta: Graha IImu

Thiagarajan. $1974 . \quad$ Instructional Development for Training Teachers of Exceptional Children. Washinton DC: National Center for Improvement Educational System. 